\title{
Diet, Nutrition and Inflammatory Bowel Diseases: Understanding the Connection- A General Pediatrician perspective
}

\author{
Aziz Koleilat* \\ Department of pediatrics, Makassed University General Hospital Beirut- LEBANON, UK
}

Submission: May 13, 2017; Published: May 30, 2017

*Corresponding author: Aziz Koleilat, Department of Pediatrics, Makassed University General Hospital, Associate Professor Arab University, Beirut- Lebanon, Vice General Secretary Pan Arab Society for Pediatric Gastroenterology, Hepatology And, UK, Email: drkoleilat@hotmail.com

Abbreviations: IBD: Inflammatory Bowel Disease; CD: Crohn's Disease; UC: Ulcerative Colitis

\section{Perspective}

\section{Why is DIET in IBD a "HOT" Topic?}

- "You are what you eat"

This phrase has come to us via quite a tortuous route.

Anthelme Brillat-Savarin wrote, in Physiologie du Gout, ou Meditations de Gastronomie Transcendante, 1826: "Dis-moi ce que tu manges, je te dirai ce que tu es." [Tell me what you eat and I will tell you what you are].

The phrase, "you are what you eat" is literally true. Nutrients from the foods you eat provide the foundation of the structure, function, and integrity of every little cell in your body, from your skin and hair to your muscles, bones, digestive and immune systems (Gray Martin 2017, The phrase finder)[1-6].

Inflammatory bowel disease (IBD) is a chronic relapsingremitting immune disorder of unknown etiology. The major phenotypes of IBD are Crohn's disease (CD) and ulcerative colitis (UC). IBD was initially recognized as a major health complication in developed countries but now it is becoming recognized in developing ones. The rise in the incidence and the prevalence of IBD has paralleled the social and economic development of populations and adaptation to a Western lifestyle that includes diet changes, especially among child and infant age groups. The rise in IBD around the world may be best explained by changes in the world's diet and nutrition which is an important parts of IBD management [7]. Understanding the importance of diet and nutrition in inflammatory bowel diseases (IBD) is vital to improve the quality of life for these patients [8]. The dietary strategies are helpful in controlling IBD symptoms and the role of diet in controlling IBD seems to make sense and a reason to consider a dietary contributor to intestinal disease, since the inflamed gut feels worse when food passes through it. No evidence that diet can cause or cure inflammatory bowel diseases (IBD). But surely contribute to treatment approach [9-13].

IBD is not related to food allergy but symptoms may be worsened by food intolerance. Proper diet may Improve symptoms of IBD and enable healing. Children with IBD are prone to becoming malnourished due to Loss of appetite (nausea, abdominal pain) [14-16], Poor digestion and absorption of nutrients, overall the chronicity of this disease tends to increase calorie needs of the body (Crohn's disease, in particular) Maintaining good nutrition with medications are more effective for healing, immunity, improve energy level, prevent, minimize gastrointestinal symptoms and normalize bowel function [15]. Where by poor nutrition or malnutrition with Loss of nutrients may cause growth effects in children and teenagers, and impact on hormone levels on girls. Natural and artificial nutrition or the combination of two can be chosen for supporting therapy of IBD. Macronutrient and micronutrient assessment should be an essential part of nutritional management $f$ patients with IBD combining the drug treatments for better life quality, The part of the probiotics must not be forgotten since its effect becoming clear and effective, probiotics role as regulation of intestinal microbial homeostasis $[17,18]$, interfere with the ability of pathogens to colonize and infect the mucosa, modulate of local and systemic immune responses, stabilize or maintenance of the gastrointestinal barrier function, inhibit of pro carcinogenic enzymatic activity and the induction of enzymatic activity that 
favors good nutrition and last but not least regulate dysbiosisi and improved microbial diversity.

\section{References}

1. Cosnes J, Gower-Rousseau C, Seksik P, Cortot A (2011) Epidemiology and natural history of inflammatory bowel diseases. Gastroenterology 140(6): 1785-1794.

2. Thia KT, Loftus EV, Sandborn WJ, Yang SK (2008) An update on the epidemiology of inflammatory bowel disease in Asia. Am J Gastroenterol 103(12): 3167-3182.

3. Yap J, Wesley A, Mouat S, Chin S (2008) Paediatric inflammatory bowel disease in New Zealand. N Z Med J 121(1283): 19-34.

4. Bach JF (2002) The effect of infections on susceptibility to autoimmune and allergic diseases N Engl J Med 347(12): 911-920.

5. Holger Garn, Joana F Neves, Richard S Blumberg, Harald Renz (2013) Effect of barrier microbes on organ-based inflammation. J Allergy Clin Immunol 131(6): 1465-1478.

6. Russell SL, Finlay BB (2012) The impact of gut microbes in allergic diseases. Curr Opin Gastroenterol 28(6): 563-569.

7. Mark Pimentel (2012) Intestine Microbes in Gastroenterology: Health and Disease. Am J Gastroenterol Suppl 1: 1-1.

8. Shanahan F (2000) AntiTNF Therapy for Crohn's Disease: A Perspective (Infliximab Is Not the Drug We Have Been Waiting For). Inflammatory Bowel Diseases 6(2): 137-139.

9. Swidsinski A, Ladhoff A, Pernthaler A, Swidsinski S, LoeningBaucke V, et al. (2002) Mucosal flora in inflammatory bowel disease. Gastroenterology 122(1): 44-54.

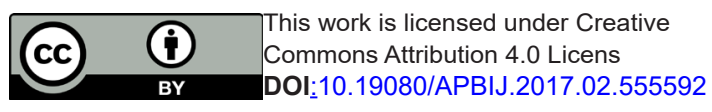

10. Asakura H, Suzuki K, Kitahora T, Morizane T (2008) Is There a Link Between Food and Intestinal Microbes and the Occurrence of Crohn's Disease and Ulcerative Colitis? J Gastroenterol Hepatol 23(12): 17941801.

11. Filippi J, Al-Jaouni R, Wiroth JB, Hébuterne X, Schneider SM (2006) Nutritional deficiencies in patients with Crohn's disease in remission. Inflamm Bowel Dis 12(3): 185-191.

12. Heuschkel R, Salvestrini C, Beattie RM, Hildebrand H, Walters T, et al. (2008) Guidelines for the management of growth failure in childhood inflammatory bowel disease. Inflamm Bowel Dis 14(6): 839-849.

13. Sakamoto N, Kono S, Wakai K, Fukuda Y, Satomi M, et al. (2005) Dietary risk factors for inflammatory bowel disease: a multicenter casecontrolstudy in Japan. Inflamm Bowel Dis 11(2): 154-163.

14. Monica Boirivant, Warren Strober (2007) The Mechanism of Action of Probiotics. Curr Opin Gastroenterol 23(6): 679-692.

15. Langlands SJ, Hopkins MJ, Coleman N, Cummings JH (2004) Prebiotic carbohydrates modify the mucosal associated microflora of the human large bowel. Gut 53(11): 1610-1616.

16. Hanai H, Kanauchi O, Mitsuyama K, Andoh A, Takeuchi K, et al (2004) Germinated barley foodstuff prolongs remission in patients withulcerative colitis. Int J Mol Med 13(5): 643-647.

17. Furrie E, Macfarlane S, Kennedy A, Cummings JH, Walsh SV, et al. (2005) Synbiotic therapy (Bifidobacterium longum / Synergy 1) initiates resolution of inflammation in patients with active ulcerative colitis: a randomised controlled pilot trial. Gut 54(2): 242-249.

18. Swidsinski A, Ladhoff A, Pernthaler A, Swidsinski S, LoeningBaucke V, et al. (2002) Mucosal flora in inflammatory bowel disease. Gastroenterology 122(1): 44-54.

\section{Your next submission with Juniper Publishers} will reach you the below assets

- Quality Editorial service

- Swift Peer Review

- Reprints availability

- E-prints Service

- Manuscript Podcast for convenient understanding

- Global attainment for your research

- Manuscript accessibility in different formats ( Pdf, E-pub, Full Text, Audio)

- Unceasing customer service

Track the below URL for one-step submission https://juniperpublishers.com/online-submission.php 